Atmos. Chem. Phys., 18, 12329-12343, 2018

https://doi.org/10.5194/acp-18-12329-2018

(C) Author(s) 2018. This work is distributed under

the Creative Commons Attribution 4.0 License.

\title{
Mercury distribution in the upper troposphere and lowermost stratosphere according to measurements by the IAGOS-CARIBIC observatory: 2014-2016
}

\author{
Franz Slemr ${ }^{1}$, Andreas Weigelt ${ }^{2, a}$, Ralf Ebinghaus ${ }^{2}$, Johannes Bieser ${ }^{2}$, Carl A. M. Brenninkmeijer ${ }^{1}$, \\ Armin Rauthe-Schöch ${ }^{1, \mathrm{~b}}$, Markus Hermann ${ }^{3}$, Bengt G. Martinsson ${ }^{4}$, Peter van Velthoven ${ }^{5}$, Harald Bönisch ${ }^{6}$, \\ Marco Neumaier ${ }^{6}$, Andreas Zahn ${ }^{6}$, and Helmut Ziereis ${ }^{7}$ \\ ${ }^{1}$ Max-Planck-Institut für Chemie (MPI), Air Chemistry Division, Hahn-Meitner-Weg 1, 55128 Mainz, Germany \\ ${ }^{2}$ Helmholtz-Zentrum Geesthacht (HZG), Institute of Coastal Research, Max-Planck-Str. 1, 21502 Geesthacht, Germany \\ ${ }^{3}$ Leibniz-Institut für Troposphärenforschung (Tropos), Permoserstr. 15, 04318 Leipzig, Germany \\ ${ }^{4}$ University of Lund, Division of Nuclear Physics, P.O. Box 118, 22100 Lund, Sweden \\ ${ }^{5}$ Royal Netherlands Meteorological Institute (KNMI), P.O. Box 201, 3730 AE, de Bilt, the Netherlands \\ ${ }^{6}$ Institute of Meteorology and Climate Research (IMK), Karlsruhe Institute of Technology, Hermann-von-Helmholtz-Platz, \\ 76344 Eggenstein-Leopoldshafen, Germany \\ ${ }^{7}$ Deutsches Zentrum für Luft- und Raumfahrt (DLR), Institut für Physik der Atmosphäre, 82230 Wessling, Germany \\ anow at: Bundesamt für Seeschifffahrt und Hydrographie (BSH), Wüstland 2, 22589 Hamburg, Germany \\ b now at: Deutscher Wetterdienst, Global Precipitation Climatology Centre, Frankfurter Straße 135, \\ 63067 Offenbach/Main, Germany
}

Correspondence: Franz Slemr (franz.slemr@mpic.de)

Received: 29 December 2017 - Discussion started: 8 February 2018

Revised: 27 July 2018 - Accepted: 9 August 2018 - Published: 27 August 2018

\begin{abstract}
Mercury was measured onboard the IAGOSCARIBIC passenger aircraft from May 2005 until February 2016 during near monthly sequences of mostly four intercontinental flights from Germany to destinations in North and South America, Africa and South and East Asia. Most of these mercury data were obtained using an internal default signal integration procedure of the Tekran instrument but since April 2014 more precise and accurate data were obtained using post-flight manual integration of the instrument raw signal. In this paper we use the latter data.

Increased upper tropospheric total mercury (TM) concentrations due to large scale biomass burning were observed in the upper troposphere (UT) at the equator and southern latitudes during the flights to Latin America and South Africa in boreal autumn (SON) and boreal winter (DJF). TM concentrations in the lowermost stratosphere (LMS) decrease with altitude above the thermal tropopause but the gradient is less steep than reported before. Seasonal variation of the vertical TM distribution in the UT and LMS is similar to that of other trace gases with surface sources and stratospheric sinks. Spe-
\end{abstract}

ciation experiments suggest comparable TM and gaseous elementary mercury (GEM) concentrations at and below the tropopause leaving little space for $\mathrm{Hg}^{2+}$ (TM - GEM) being the dominating component of TM here. In the stratosphere significant GEM concentrations were found to exist up to $4 \mathrm{~km}$ altitude above the thermal tropopause. Correlations with $\mathrm{N}_{2} \mathrm{O}$ as a reference tracer suggest stratospheric lifetimes of $72 \pm 37$ and $74 \pm 27$ years for TM and GEM, respectively, comparable to the stratospheric lifetime of COS. This coincidence, combined with pieces of evidence from us and other researchers, corroborates the hypothesis that $\mathrm{Hg}^{2+}$ formed by oxidation in the stratosphere attaches to sulfate particles formed mainly by oxidation of COS and is removed with them from the stratosphere by air mass exchange, gravitational sedimentation and cloud scavenging processes. 


\section{Introduction}

Mercury is an element whose high vapor pressure leads to significant emissions into the atmosphere. Measurements of atmospheric mercury show a relatively even distribution over the globe (Sprovieri et al., 2010) with background concentrations varying mostly between $1-2 \mathrm{ng} \mathrm{m}^{-3}$. After oxidation to less volatile and more soluble compounds, mercury is deposited and becomes bioavailable. Its conversion to the highly neurotoxic methyl mercury, which bioaccumulates in the aquatic nutritional chain to concentrations dangerous for humans and animals has motivated intensive research on the biogeochemical cycle of mercury (e.g., Mergler et al., 2007; Scheuhammer et al., 2007; Lindberg et al., 2007; AMAP/UNEP, 2018 and references therein).

Despite decades of research, the atmospheric mercury cycle is still not well understood (Lin et al., 2006; Lindberg et al., 2007; Ariya et al., 2015). Several mechanisms of elemental mercury oxidation in the gas phase have been proposed (Selin et al., 2007; Holmes et al., 2010; Dibble et al., 2012; Horowitz et al., 2017; Travnikov et al., 2017) but their relative importance is still unknown (Lin et al., 2006; Travnikov et al., 2017). Neither have the oxidation products been unequivocally identified so far because of the lack of speciation techniques for individual mercury compounds (Gustin et al., 2015; Ariya et al., 2015). In addition, attempts to constrain the atmospheric mercury cycle using different models had to rely almost exclusively on measurements at the surface in the Northern Hemisphere, which undermined these efforts. Measurements of mercury distribution in the troposphere and stratosphere by research aircraft are expensive and thus usually limited to short-term campaigns covering small regions of the globe (Ebinghaus and Slemr, 2000; Friedli et al., 2001, 2003a, 2004; Banic et al., 2003; Ebinghaus et al., 2007; Radke et al., 2007; Talbot et al., 2007, 2008; Swartzendruber et al., 2008; Slemr et al., 2009, 2014; Lyman and Jaffe, 2012; Brooks et al., 2014; Ambrose et al., 2015; Gratz et al., 2015; Shah et al., 2016; Weigelt et al., 2016a, b). These aircraft measurements have so far provided information about the emissions of mercury from biomass burning (Friedli et al., 2001, 2003a, b; Ebinghaus et al., 2007) and from industrial sources (Friedli et al., 2004; Talbot et al., 2008; Swartzendruber et al., 2008; Slemr, et al., 2014; Ambrose et al., 2015; Weigelt et al., 2016b), with sometimes differing information about the vertical distribution of mercury (Ebinghaus and Slemr, 2000; Radke et al., 2007; Talbot et al., 2007, 2008; Slemr et al., 2009; Lyman and Jaffe, 2012; Brooks et al., 2014; Shah et al., 2016; Weigelt et al., 2016a; Bieser et al., 2017). In addition, a pronounced depletion of elemental mercury in air masses influenced by the stratosphere has been reported (Ebinghaus et al., 2007; Radke et al., 2007; Talbot et al., 2007, 2008; Swartzendruber et al., 2008; Slemr et al., 2009; Lyman and Jaffe, 2012). However, because of temporal and spatial limitations resulting from the costs of research aircraft, hardly any information on seasonal varia- tion of mercury concentrations in the upper troposphere (UT) and lowermost stratosphere (LMS) has been obtained so far.

IAGOS-CARIBIC (In-service Aircraft for a Global Observing System - Civil Aircraft for Regular Investigation of the Atmosphere Based on an Instrumented Container) project offers a possibility of regular large scale sounding of trace constituent distributions in the UT/LMS using an instrumented container flown onboard a passenger aircraft during intercontinental flights (Brenninkmeijer et al., 2007; www.caribic-atmospheric.com, last access: $16 \mathrm{Au}-$ gust 2018). From May 2005 until February 2016 mercury was measured with a modified Tekran instrument in combination with a large suite of other trace gases and particles onboard the CARIBIC aircraft (Brenninkmeijer et al., 2007; Slemr et al., 2009, 2014, 2016; GMOS, 2018). Mercury data collected during near monthly sequences of mostly four intercontinental flights from Germany to destinations in North and South America, Africa and East and South Asia represent the largest mercury data set obtained in the UT and LMS so far. Most mercury data were obtained using the Tekran internal default signal integration procedure but since April 2014 we manually integrated the Tekran raw signal. This postflight integration of the raw signal substantially improved the detection limit and precision of the mercury measurements and removed negative bias of the default integration leading to the occasional occurrence of zero concentrations in the data before April 2014 (Slemr et al., 2016; Ambrose, 2017). Raw signal data are available only since April 2014 and older data cannot be reintegrated. We use the recent, smaller but higher quality dataset here, in an attempt to unravel the behavior of mercury in the UT/LMS.

\section{Experimental}

The CARIBIC container (Brenninkmeijer et al., 2007; www. caribic-atmospheric.com) onboard an Airbus 340-600 of Lufthansa holds automated analyzers for gaseous mercury, $\mathrm{CO}, \mathrm{O}_{3}, \mathrm{NO}, \mathrm{NO}_{y}, \mathrm{CO}_{2}, \mathrm{CH}_{4}$, acetone, acetonitrile, water vapor (total, gaseous, isotope composition) and fine aerosol particles (three counters for particles with lower threshold diameters of 4, 12 and $18 \mathrm{~nm}$, upper cut off about $2.0 \mu \mathrm{m}$ ), as well as an optical particle size spectrometer (OPSS) for particles with diameters $>150 \mathrm{~nm}$. In addition, whole air and aerosol particle samples are taken in flight and subsequently analyzed for greenhouse gases, halocarbons, hydrocarbons and particle elemental composition. The CARIBIC measurement container is usually deployed monthly during a sequence of four intercontinental flights.

The air inlet system and the mercury instrument are described in detail by Brenninkmeijer et al. (2007) and Slemr et al. (2016), respectively. Briefly, the trace gas inlet consists of a trace gas diffuser tube with a flow of more than 2000 volume- $\mathrm{L} \mathrm{min}^{-1}$ from which $\sim 80$ volume- $\mathrm{L} \mathrm{min}^{-1}$ is taken at a right angle to a manifold, which supplies the 
trace gas analyzers in the container via a temperature controlled PFA lined supply tube. The high air velocity in the trace gas diffuser tube combined with perpendicular sampling at a much smaller velocity discriminates against particles larger than about $1 \mu \mathrm{m}$ in diameter $(\sim 50 \%$ aspiration efficiency, Baron and Willeke, 2001). A modified Tekran instrument (Tekran-Analyzer Model 2537 A, Tekran Inc., Toronto, Canada) samples nominally $0.5 \mathrm{~L}$ (STP) $\mathrm{min}^{-1}$ of air from the supply line manifold (heated to $40^{\circ} \mathrm{C}$ ) using the $4 \mathrm{~mm}$ ID PFA tubing at about $30^{\circ} \mathrm{C}$. The major modifications of the instrument were the addition of a second pump supporting the internal Tekran pump and of a computer that communicates with the container's master computer and controls the automatic operation of the instrument. For the period August 2014 until February 2016 a quartz wool scrubber was installed in the instrument to filter out gaseous oxidized mercury (GOM).

To achieve an improved spatial resolution of $\sim 75 \mathrm{~km}$, the instrument was run with a sampling time of only 5 min. Despite an additional pump the nominal flow of $0.5 \mathrm{~L}$ (STP) $\min ^{-1}$ could not be sustained at the highest flight levels. Limited air flow, the short sampling time and low concentrations resulted in only $\sim 2$ pg of mercury, which is much smaller than $10 \mathrm{pg}$ considered as minimum for biasfree internal default integration of the signal by the Tekran instrument (Swartzendruber et al., 2009; Slemr et al., 2016; Ambrose, 2017). For this reason, as previously mentioned, the raw analyzer signals were processed post-flight using a manual integration procedure described in detail by Slemr et al. (2016). The detection limit and precision with post-flight processing is estimated to be $\sim 0.05 \mathrm{ng} \mathrm{m}^{-3}$. The instrument is calibrated after every second flight sequence through comparison measurements with a calibrated reference Tekran instrument in the laboratory. All mercury concentrations are reported in $\mathrm{ng} \mathrm{Hg} \mathrm{m}^{-3}$ (STP).

As discussed in detail by Slemr et al. (2016) we assume that our measurements encompass gaseous elemental mercury (GEM), gaseous oxidized mercury (GOM) and about $70 \%$ of particle bound mercury (PBM). Speciation experiments using soda lime $\left(\mathrm{Ca}(\mathrm{OH})_{2}\right.$ with $\left.\mathrm{NaOH}\right)$ and $\mathrm{KCl}$ coated quartz sand as GOM scrubbers made during several flights demonstrated that GOM does pass through the CARIBIC air sampling system. According to the extrapolation of the reported GOM/PBM (GOM and PBM are both assumed to be $\mathrm{Hg}^{2+}$, i.e., $\mathrm{PBM}+\mathrm{GOM}=\mathrm{Hg}^{2+}$ ) partitioning equilibria (Rutter and Schauer, 2007; Amos et al., 2012) from ambient temperatures near ground to about $-50^{\circ} \mathrm{C}$ around the tropopause, most of $\mathrm{Hg}^{2+}$ will be attached to particles. Although the CARIBIC trace gas inlet is not optimized to collect particles (see above), we estimated that nevertheless particles with diameter of $<0.5 \mu \mathrm{m}$ will pass through it, representing $\sim 70 \%$ of the aerosol mass. Despite of significant PBM concentrations in the stratosphere reported by Murphy et al. (1998, 2006), we were not able to detect mercury in the aerosol samples collected by the
CARIBIC impactor sampler that uses an inlet optimized for quantitative particle sampling (for a recent publication on aspects of the CARIBIC aerosol impactor please see Martinsson et al., 2015). Although not equipped with heaters, the air flow carrying the particles will warm up to $\sim 30^{\circ} \mathrm{C}$ on the way from the aerosol inlet to the impactor. In view of this, our inability to detect mercury in particle samples thus suggests that $\mathrm{Hg}^{2+}$ on particles evaporates when the sample air is heated to $\sim+30^{\circ} \mathrm{C}$ in the inlet tubing and forms GOM. In summary, we assume that our measurements are close to total mercury $\left(\mathrm{TM}=\mathrm{GEM}+\mathrm{Hg}^{2+}=\mathrm{GEM}+\mathrm{GOM}+\mathrm{PBM}\right)$ concentration and we refer to them as such.

In order to get information about the GEM fraction, sample air was passed through a quartz wool scrubber for GOM during the outbound flights between August 2014 and February 2016. The method using quartz wool to capture GOM in order to measure GEM, called DOHGS (Detector for Oxidized $\mathrm{Hg}$ Species), is described by Lyman and Jaffe (2012) and Ambrose et al. (2013), and the measurements made by this technique have been reported by Lyman and Jaffe (2012), Ambrose et al. (2013, 2015), Gratz et al. (2015) and Shah et al. (2016). The DOHGS took part in the Reno Atmospheric Mercury Intercomparison eXperiment (RAMIX) whose results have been controversially discussed by Gustin et al. (2013), Ambrose et al. (2013) and Hynes et al. (2017). According to Gustin et al. (2013) and Ambrose et al. (2013) GOM measurements by the DOHGS technique agreed well with nylon and cation exchange filters while yielding substantially higher values than the Tekran speciation system. Hynes et al. (2017), on the other hand, found a good agreement of GOM concentrations measured by two-photon laser-induced fluorescence (2P-LIF) with and without a pyrolyzer (the 2P-LIF technique can measure GEM directly without using any filter) and by the Tekran speciation system. According to their interpretation DOHGS overestimated GOM concentrations (underestimated GEM). In summary, the results of RAMIX were inconclusive. As described in supplementary information (SI) our GEM data obtained by using quartz wool traps may have been biased both by the method itself and by the way we used them. The data we obtained using the quartz wool scrubber and presented here as GEM can thus be interpreted only in qualitative terms. We also note that the tracks and altitudes of the outbound and return flights differ sometimes substantially, especially in the case of the flights to North America (the flight tracks from Germany to North America tend to be substantially further north than those of the return flights). This means that the TM and GEM data are not directly comparable even if they were measured on the same day. For half of the (outbound) flights during which the quartz wool scrubber was deployed, GEM concentrations at the beginning of the flight were significantly higher than those of TM during the entire return flight and the differences decreased during the flight indicating contamination that disappeared during the $8-10 \mathrm{~h}$ flight. We found that the contamination had started to occur 


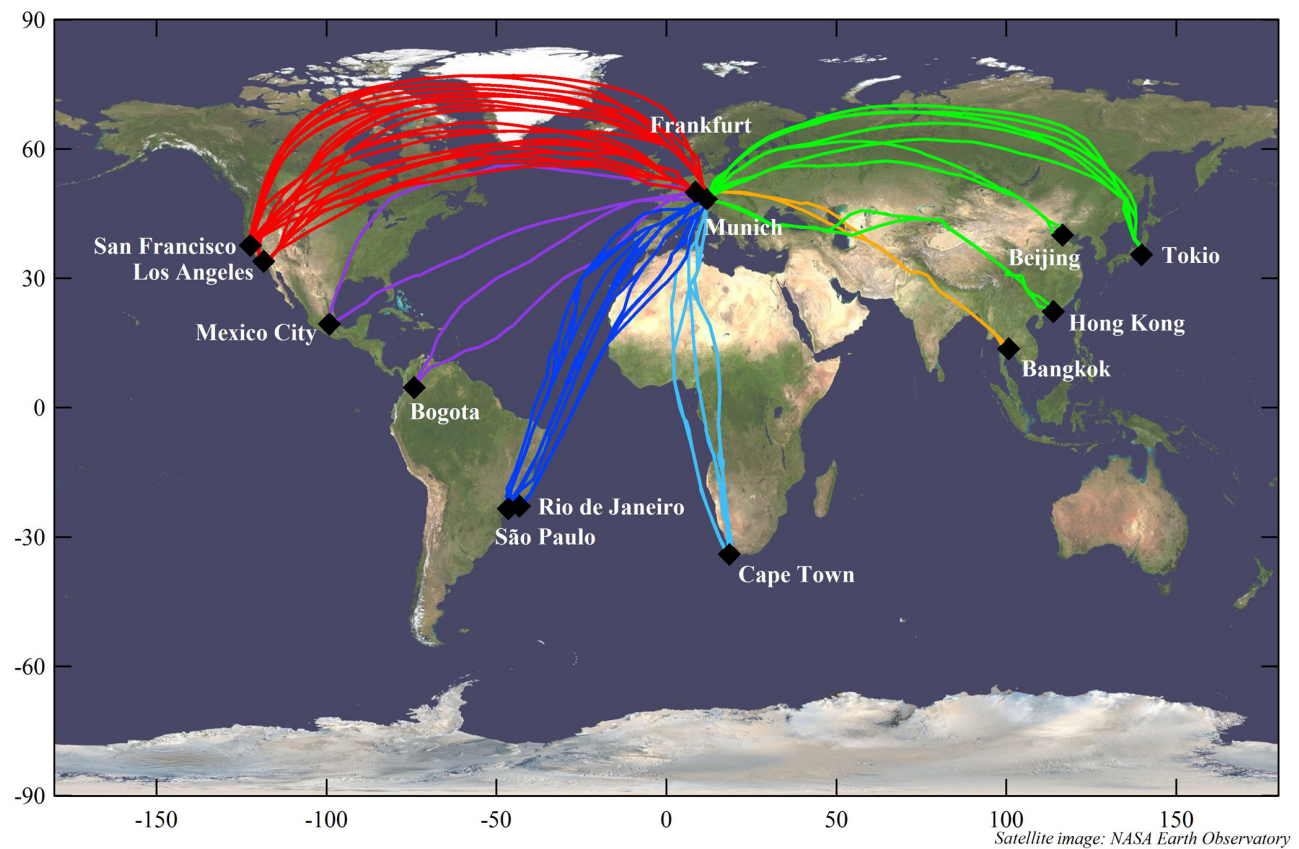

Figure 1. Tracks of the CARIBIC flights made between April 2014 and February 2016 (CARIBIC flights no. 468-536). Mercury data for these flights were obtained by post-flight processing of the Tekran raw signal (Slemr et al., 2016).

after a change of the personnel preparing the instrument and we thus attribute the contamination effect it to this change. These data (half of the outward bound flight results) were eliminated from the data set.

The data we report here were obtained during flights between April 2014 and February 2016 whose tracks are shown in Fig. 1. All but one monthly flight sequences consisted of four individual intercontinental flights. The altitude of these flights varies typically from $\sim 9 \mathrm{~km}$ at the beginning of the flight to $11-12 \mathrm{~km}$ at the end before the final descent. In addition to the meteorological data provided by the aircraft, meteorological parameters along the flight track were calculated from the ECMWF (European Centre for Medium Range Weather Forecasts) data (6-hourly, 60 model levels until February 2006 and 90 model levels thereafter, $1^{\circ} \times 1^{\circ}$ horizontal resolution). Eight days backward, 3-D kinematic trajectories were calculated with the KNMI model TRAJKS (Scheele et al., 1996, http://projects.knmi.nl/campaign support/CARIBIC/, last access: 16 August 2018) at oneminute intervals along the flight path. Consequently, five trajectories were available for each mercury measurement. The data set consists of 33 and 17 individual flights with valid TM and GEM data, respectively.

For the data evaluation, the relevant concomitant meteorological and trace gas data were averaged over the sampling intervals of mercury measurements.

\section{Results and discussion}

\subsection{Latitudinal TM distribution in the upper troposphere}

Figure 2 shows latitudinal distribution of TM in the upper troposphere: defined as TM concentrations at potential vorticity (PV) of $-1.5 \leq \mathrm{PV} \leq 1.5 \mathrm{PVU}$ ( $1 \mathrm{PVU}=10^{-6} \mathrm{~K} \mathrm{~m}^{2} \mathrm{~kg}^{-1} \mathrm{~s}^{-1}$ ) observed during the flights to South America (Bogota, São Paulo and Rio de Janeiro) in boreal summer (only July and August), fall (September, October, November) and winter (December, January, February). Corresponding latitudinal distributions of acetonitrile (AN, originating almost solely from biomass burning) and of $\mathrm{CO}$ and $\mathrm{CH}_{4}$ with large emissions from biomass burning (Andreae and Merlet, 2001) are also shown. The lowest TM concentrations are observed in the latitude bands of 10-20 and $20-30^{\circ} \mathrm{S}$ in summer (JA) and the same applies for $\mathrm{CO}, \mathrm{CH}_{4}$ and acetonitrile. The highest TM concentrations in $20-30^{\circ} \mathrm{S}$ latitude band are observed in fall (SON) and the TM concentrations decrease in winter (DJF) as do the $\mathrm{CO}$ and acetonitrile mixing ratios in the $10-20^{\circ} \mathrm{S}$ latitude band. The highest $\mathrm{CO}$ and $\mathrm{CH}_{4}$ mixing ratios at $20-30^{\circ} \mathrm{S}$ are observed in winter with mixing ratios in fall somewhat lower. Biomass burning in South America starts in June, peaks in September and ends in December (Duncan et al., 2003). TM concentrations in the southernmost latitude bands follow this seasonal variability as do the acetonitrile, $\mathrm{CO}$ and $\mathrm{CH}_{4}$ mixing ratios at $10-20^{\circ} \mathrm{S}$ latitude. In the latitude band $20-30^{\circ} \mathrm{S}$ the $\mathrm{CO}$ and $\mathrm{CH}_{4}$ mixing ratios are higher in boreal 


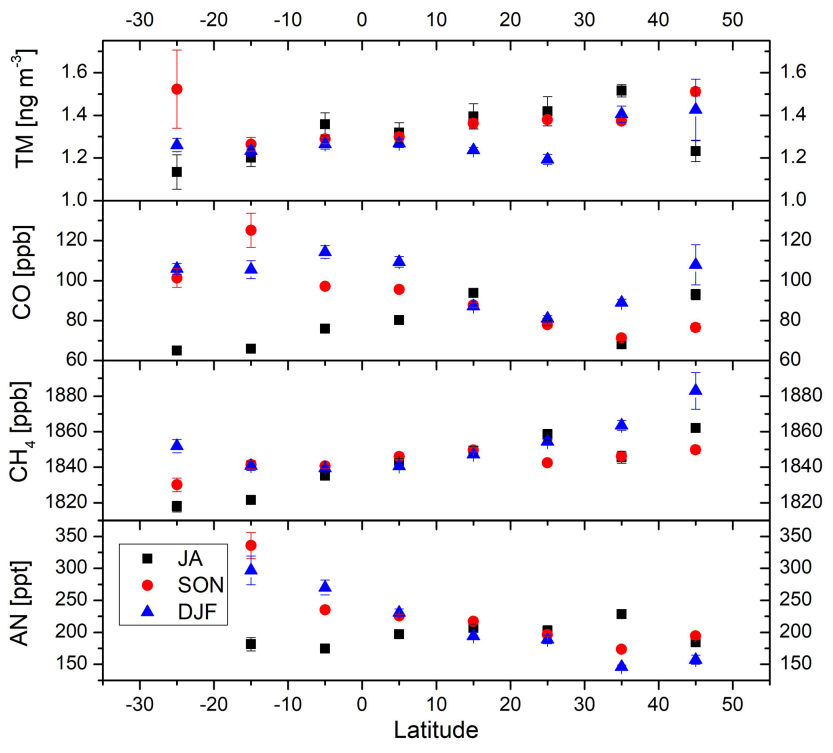

Figure 2. Latitudinal distributions of tropospheric (PV $\leq 1.5 \mathrm{PVU})$ $\mathrm{TM}, \mathrm{CO}, \mathrm{CH}_{4}$ and acetonitrile (AN) during the flights from Bogota and São Paulo and Rio de Janeiro to Munich in summer (only July and August, JA), autumn (September, October and November, SON) and winter (December, January and February, DJF). The points represent averages and the vertical bars their standard error. No acetonitrile data were available south of $20^{\circ} \mathrm{S}$.

winter than in fall. This might result from larger additional $\mathrm{CO}$ and $\mathrm{CH}_{4}$ sources in boreal winter such as from oxidation of volatile organic compounds and wetlands. It is also worth noting that in boreal fall and winter the acetonitrile and $\mathrm{CO}$ mixing ratios in the monitored part of the Southern Hemisphere are higher than in the Northern Hemisphere. In summary, Fig. 2 illustrates the large-scale influence of biomass burning on the latitudinal TM distribution in the upper troposphere of the Southern Hemisphere.

The role of biomass burning is further illustrated by means of Fig. 3, comparing the South America boreal winter profiles of the four trace constituents with those for South Africa (Cape Town). Acetonitrile and $\mathrm{CO}$ mixing ratios from flights to South Africa show a pronounced bulge between $30^{\circ} \mathrm{S}$ and $20^{\circ} \mathrm{N}$ peaking around the equator. The same applies to results for the flights to South America, be it with somewhat lower values and more southern maximum for acetonitrile. For both flight routes $\mathrm{CO}$ and acetonitrile mixing ratios are higher in the southern than in the Northern Hemisphere. Boreal winter (DJF) is an intermediate season between biomass emissions peaking in September in southern Africa and in January in northern Africa (Duncan et al., 2003). The latitudinal pattern of $\mathrm{CH}_{4}$ is less clear, with wetlands also being a major source. Finally, Fig. 3 shows a similarity between TM and the biomass burning indicators in the tropics at flight altitude.

Biomass burning plumes with enhanced mercury concentrations have been reported before (Brunke et al., 2001;
Friedli et al., 2001, 2003a, b; Ebinghaus et al., 2007; Slemr et al., 2014; among others). Emitting $675 \mathrm{Mg} \mathrm{yr}^{-1}$ of mercury, biomass burning is estimated to be the third largest source after emissions from oceans $\left(2682 \mathrm{Mg} \mathrm{yr}^{-1}\right)$ and from fossil-fuel power plants $\left(810 \mathrm{Mg} \mathrm{yr}^{-1}\right.$; Friedli et al., 2009; Pirrone et al., 2010). Figures 2 and 3 illustrate the influence of biomass burning on the large-scale distribution of TM in the Southern Hemispheric UT.

Acetonitrile mixing ratios in winter (DJF) shown in Fig. 3 are the lowest in the northernmost latitude bands $20-50^{\circ} \mathrm{N}$. The concomitant elevated TM concentrations and $\mathrm{CO}$ and $\mathrm{CH}_{4}$ mixing ratios are thus mostly due to anthropogenic emissions. An exception is the highest TM concentration observed at $30-40^{\circ} \mathrm{N}$ (Fig. 2) in summer (JA), which coincides with the peak of acetonitrile mixing ratio in the Northern Hemisphere. The respective data originate from the flight no. 475 from São Paulo to Munich on 21 August 2014. Two whole air samples were taken within this latitude band of which sample no. 12 coincides with the peak acetonitrile, acetone, $\mathrm{CO}$ and $\mathrm{CH}_{4}$ mixing ratios. In addition, sample no. 12 contains high ethane and propane mixing ratios (786 and $126 \mathrm{ppt}$, respectively) as well as somewhat elevated $\mathrm{CH}_{4}$ and $\mathrm{SF}_{6}$ mixing ratios. Sample no. 12 was taken over southwestern Spain and its 8 days backward trajectory crosses the Atlantic Ocean, eastern US, Great Lakes up to the Californian Pacific coast. The complex composition of this sample indicates a mixture of anthropogenic pollution with emissions from biomass burning. The latter is additionally supported by fire maps (https://lance.modaps.eosdis.nasa.gov/imagery/ firemaps, last access: 16 August 2018) reporting individual fire counts along the trajectory in North America and especially a large fire in northern California at the time of trajectory crossing.

\subsection{Seasonal variation of the vertical TM distribution in the upper troposphere and lowermost stratosphere}

Due to the geographical location of the airport of departure and the CARIBIC destinations it happens to be that about half of the intersected air masses were situated above the tropopause. This allows a fairly representative mapping of measured trace species around the tropopause (see for instance Zahn et al., 2014). Figure 4 shows the seasonal pattern of the average TM concentrations and $\mathrm{CO}, \mathrm{CH}_{4}$ and $\mathrm{O}_{3}$ mixing ratios relative to the thermal tropopause. The distance relative to the tropopause is based on CARIBIC ozone measurements. Basically, an ozone mixing ratio measured by CARIBIC is compared to representative data from ozone soundings. As these soundings measure both thermal tropopause height and ozone, the distance relative to the tropopause is obtained (Sprung and Zahn, 2010). This value based on the CARIBIC ozone data is considered to be more accurate than PV (calculated from the ECMWFmodel) based dynamical tropopause, especially in subtrop- 


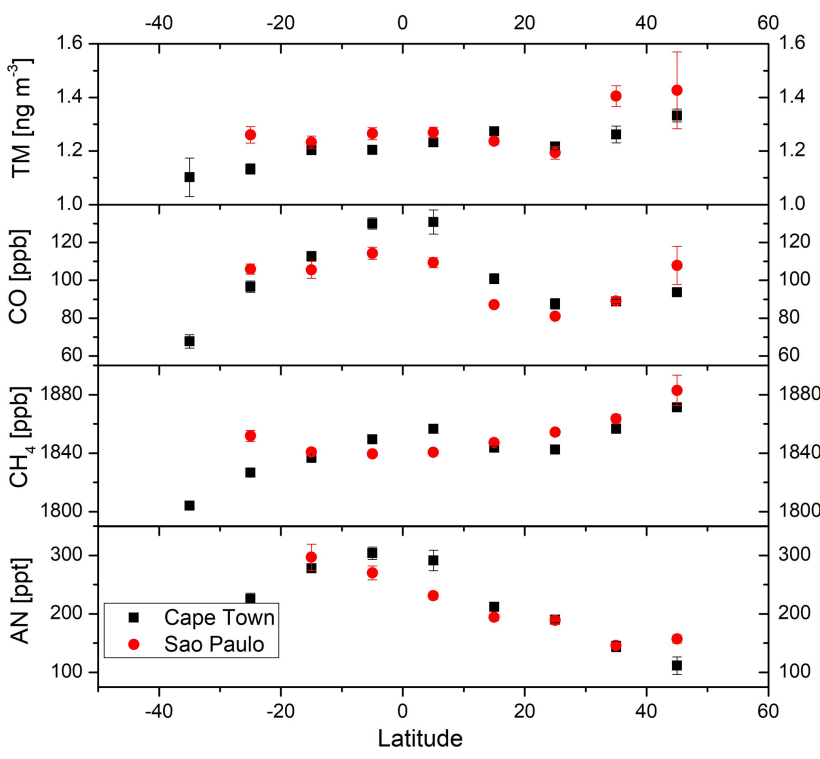

Figure 3. Latitudinal distributions of tropospheric TM, $\mathrm{CO}, \mathrm{CH}_{4}$ and acetonitrile (AN) in winter (December, January and February, DJF) during the flights from Cape Town and São Paulo to Munich. The points represent averages and the vertical bars their standard error. No acetonitrile data are available south of 30 and $20^{\circ} \mathrm{S}$ for flights to Cape Town and São Paulo, respectively.

ical latitudes where the dynamical tropopause is not well defined by a constant PV threshold value (Kunz et al., 2011). Only measurements north of $20^{\circ} \mathrm{N}$ were considered for making this plot. The seasonal variation of the vertical distributions of the trace gases and TM reflect their source location and the Brewer-Dobson circulation with a maximum content of stratospheric air in the UT/LMS in spring (Holton et al., 1995; Gettelman et al., 2011). Ozone rich air, depleted in CO, $\mathrm{CH}_{4}$ and $\mathrm{N}_{2} \mathrm{O}$ descends in spring and here the question is what happens to the mercury compounds.

The highest TM concentrations of $1.4-1.7 \mathrm{ng} \mathrm{m}^{-3}$ are encountered at $0.5-1.75 \mathrm{~km}$ below the thermal tropopause in September/October. Two thirds of these elevated TM data originate from flights from Tokyo to Munich on 30 October 2014, and Beijing to Munich on 31 October 2014, and were observed mostly within $\sim 1500 \mathrm{~km}$ of Tokyo and Beijing. High TM concentrations are accompanied by elevated $\mathrm{CO}$ and $\mathrm{CH}_{4}$ mixing ratios. Near Tokyo and Beijing elevated $\mathrm{SF}_{6}$ mixing ratios were also observed. Backward trajectories from these flight segments on 30 and 31 October point to surface contact in Tibet, Bangladesh and northern India. Slightly elevated TM concentrations encountered near Munich on 30 and 31 October are most likely due to emissions located in North America.

The lowest TM concentrations of $0.4-0.6 \mathrm{ng} \mathrm{m}^{-3}$ were encountered during the flights Tokyo to Munich (flight no. 502) on 21 April 2015, and Mexico to Munich (flight no. 504) on 22 April 2015. During both flights the lowest TM con- centrations were accompanied by $\mathrm{O}_{3}$ and $\mathrm{H}_{2} \mathrm{O}$ mixing ratios of $>400 \mathrm{ppb}$ and $<10 \mathrm{ppm}$, respectively, characteristic of deeper stratospheric air. No CO data are available for CARIBIC flight no. 502 but CO mixing ratios of $<30 \mathrm{ppb}$ for the lowest TM values during the CARIBIC flight no. 504 also point to a relatively deep stratospheric origin of the air, conform extremely low $\mathrm{SF}_{6}$ and $\mathrm{CH}_{4}$ mixing ratios in both flights.

\subsection{Speciation in the UT and LMS}

The reason to show only TM in Fig. 4, without GEM, is that (as mentioned before) about half of the GEM data was lost due to contamination problems attributed to a change of personnel preparing the instrument since October 2015. For analyzing the GEM results, we divide the data set into boreal winter (December-May) and boreal summer (JuneNovember). The upper panel of Fig. 5 shows the vertical distributions of TM and GEM in three different latitude bands for boreal winter, the lower panel shows the vertical distribution of CO measured concurrently with TM or GEM. Likewise, the upper and lower panels of Fig. 6 display the TM, GEM and CO vertical distributions in summer.

In Sect. 3.1 we have shown a close relation between mercury and $\mathrm{CO}$, the latter as a tracer for biomass burning and anthropogenic pollution. Below we use this close relation as a qualitative indicator for comparability of TM and GEM measurements during different flights. Without oxidation of GEM to GOM we expect comparable TM and GEM concentrations when $\mathrm{CO}(\mathrm{TM})$ and $\mathrm{CO}(\mathrm{GEM})$ are comparable. The data points in Figs. 5 and 6 represent concentration averages and their standard errors. Although extreme individual values were eliminated using the Nalimov outlier test (Kaiser and Gottschalk, 1972), unedited data yield similar plots. We also note that TM and GEM data from all flights were used in these figures, altogether 1528 and 1349 TM measurements in winter and summer, respectively, as well 699 and 916 GEM measurements in winter and summer, respectively.

Winter vertical distribution of $\mathrm{CO}$ mixing ratios in Fig. 5 shows, for latitudes $30-60$ and $>60^{\circ} \mathrm{N}$, a steep decrease above the thermal tropopause and essentially identical $\mathrm{CO}$ mixing ratios for measurements accompanying $\mathrm{TM}$ and GEM measurements in the stratosphere. Stratospheric TM concentrations at $30-60^{\circ} \mathrm{N}$ latitude shown in Fig. 5 are always substantially higher than those of GEM, and at $>60^{\circ} \mathrm{N}$ latitude mostly so, indicating the presence of larger $\mathrm{Hg}^{2+}$ concentrations in the stratosphere. The tropospheric GEM concentrations at $30-60^{\circ} \mathrm{N}$ latitude tend to be higher than those of TM as do CO(GEM) mixing ratios when compared with those of $\mathrm{CO}(\mathrm{TM})$. We thus surmise that the tropospheric differences are mostly due to different degree of pollution in air masses encountered during the forward and return flights. At $>60^{\circ} \mathrm{N}$ latitude there are no tropospheric TM and $\mathrm{CO}(\mathrm{TM})$ measurements for comparison with GEM and $\mathrm{CO}(\mathrm{GEM})$ because the low altitude of the thermal tropopause 

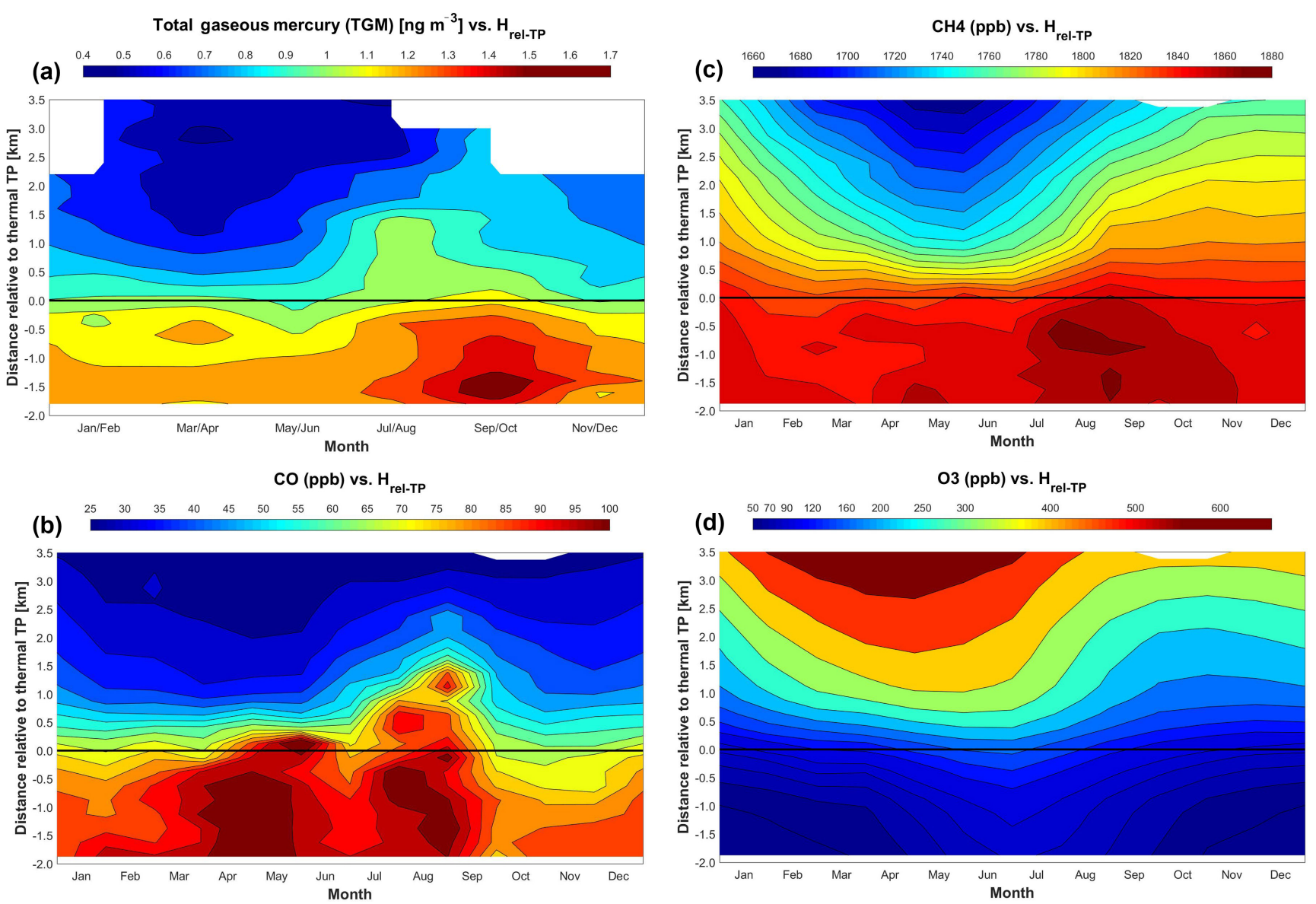

Figure 4. Seasonal variation of mean TM concentrations (a), $\mathrm{CO}(\mathbf{b}), \mathrm{CH}_{4}(\mathbf{c})$ and $\mathrm{O}_{3}(\mathbf{d})$ mixing ratios in distance relative to the thermal tropopause derived from ozone soundings according to Sprung and Zahn (2010). All TM data north of $20^{\circ} \mathrm{N}$ obtained between April 2014 and February 2016 were considered for this plot (2288 individual data points).

is mostly below the cruise altitude. Conversely, at $30^{\circ} \mathrm{S}-$ $30^{\circ} \mathrm{N}$ the aircraft generally does not reach the stratosphere. At these latitudes tropospheric TM and GEM concentrations are comparable while $\mathrm{CO}$ mixing ratios vary strongly with $\mathrm{CO}(\mathrm{GEM})$ mixing ratios, tending to smaller values than those of $\mathrm{CO}(\mathrm{TM})$. The interpretation of these data is difficult because of the large influence of biomass burning in some flights (see Sect. 3.1) and possibly because of interhemispheric mixing. Comparable TM and GEM concentrations at mostly smaller $\mathrm{CO}(\mathrm{GEM})$ than $\mathrm{CO}(\mathrm{TM})$ might indicate substantial $\mathrm{Hg}^{2+}$ contribution to TM.

In agreement with Fig. 4, TM, GEM and $\mathrm{CO}$ (Fig. 6) show less steep gradients at the tropopause in summer. At $30-60^{\circ} \mathrm{N}$ latitude the stratospheric TM and GEM concentrations follow roughly the mixing ratios of $\mathrm{CO}(\mathrm{TM})$ and $\mathrm{CO}(\mathrm{GEM})$ suggesting that the TM-GEM difference results more from the degree of pollution than from the $\mathrm{Hg}^{2+}$ content. At $>60^{\circ} \mathrm{N}$ latitude in the stratosphere $\mathrm{CO}(\mathrm{TM})$ and $\mathrm{CO}(\mathrm{GEM})$ mixing ratios are comparable while GEM concentrations tend to be substantially smaller than those of TM, which suggests the presence of substantial $\mathrm{Hg}^{2+}$ concentra- tions. The tropospheric GEM concentrations at latitudes 3060 and $>60^{\circ} \mathrm{N}$ tend to be higher than those of TM while $\mathrm{CO}(\mathrm{TM})$ and $\mathrm{CO}(\mathrm{GEM})$ mixing ratios are roughly comparable. In this case, $\mathrm{CO}$ as an indicator of air mass pollution does not work and we attribute the difference to difference in air masses. As in winter, roughly comparable TM and GEM concentrations at substantially larger $\mathrm{CO}(\mathrm{TM})$ than $\mathrm{CO}(\mathrm{GEM})$ mixing ratios at latitudes $30^{\circ} \mathrm{S}-30^{\circ} \mathrm{N}$ might indicate some $\mathrm{Hg}^{2+}$ presence.

In summary, Figs. 5 and 6 show roughly comparable tropospheric GEM and TM concentrations both in winter and in summer at latitudes $>30^{\circ} \mathrm{N}$. Comparable GEM and TM concentrations leave little scope for $\mathrm{Hg}^{2+}$ being the dominant mercury species in the upper troposphere at these latitudes. At $30^{\circ} \mathrm{S}-30^{\circ} \mathrm{N}$ tropospheric TM and GEM concentrations are roughly comparable in winter and in summer while $\mathrm{CO}(\mathrm{TM})$ tend to be substantially larger than $\mathrm{CO}(\mathrm{GEM})$ possibly suggesting the presence of substantial $\mathrm{Hg}^{2+}$ concentrations. The stratospheric GEM concentrations tend to be smaller than those of TM in winter at latitudes $>30^{\circ} \mathrm{N}$ and in summer at $>60^{\circ} \mathrm{N}$ implying substantial and possibly domi- 

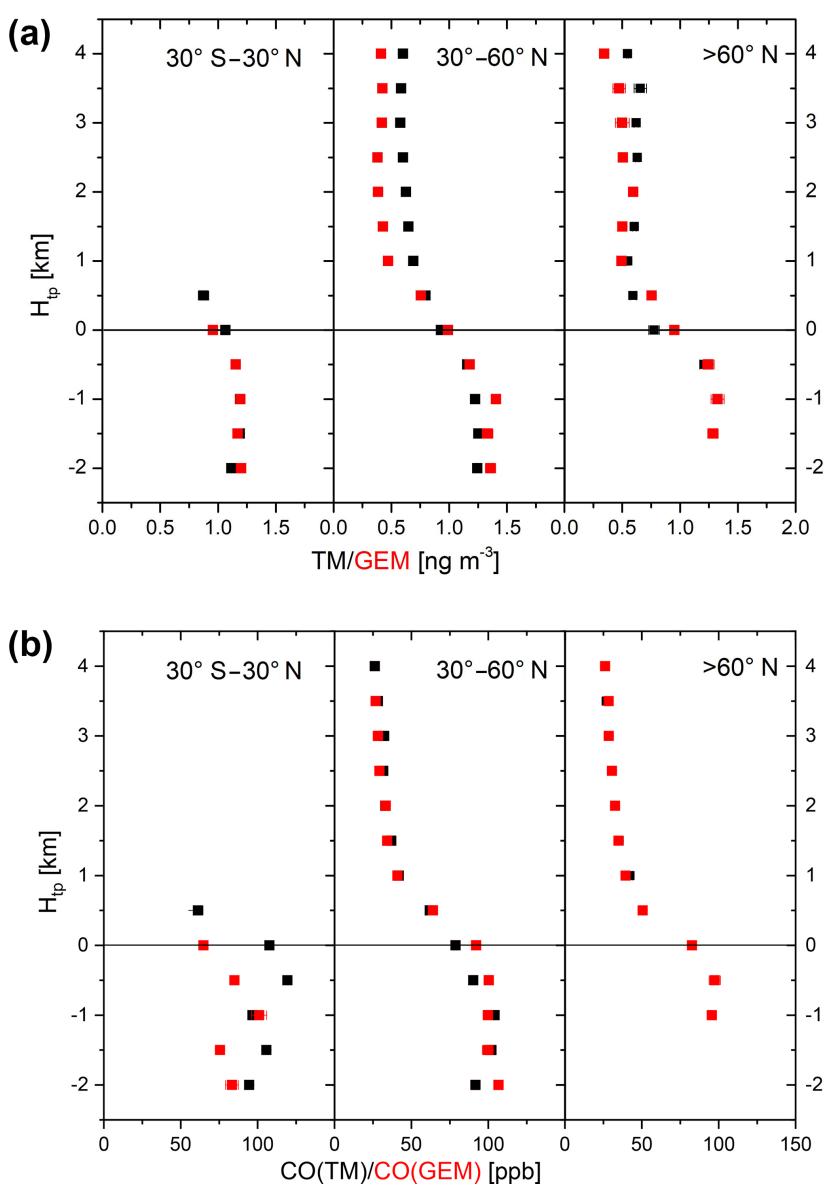

Figure 5. Vertical TM and GEM distribution relative to the thermal tropopause in winter (December-May, a). Panel (b) shows the vertical distribution of $\mathrm{CO}$ measured during the TM and GEM measurements. The data points represent averages and their standard errors, extreme values were eliminated using the Nalimov outlier test (Kaiser and Gottschalk, 1972).

nant $\mathrm{Hg}^{2+}$ concentrations. However, not a single GEM measurement out of 1615 was below the detection limit revealing the existence of significant stratospheric GEM concentrations up to $4 \mathrm{~km}$ above the thermal tropopause.

Our notion about the behavior and speciation of mercury in the UT/LMS is quite limited and based on a few measurement reports made by either a Tekran speciation system or by DOHGS. Swartzendruber et al. (2006), using a Tekran speciation system, observed at Mount Bachelor higher GOM concentration in downslope air flow than in upslope flow, which implies higher GOM concentrations in the free troposphere than in the planetary boundary layer. Talbot et al. (2007) reported a total depletion of GEM in the UT/LMS. By extrapolation of measurements made by DOHGS in stratospheric intrusions, Lyman and Jaffe (2012) derived an empirical model that predicts a total depletion of GEM at $\sim 1 \mathrm{~km}$ above the tropopause and of total mercury (including particle bond mercury, PBM) at $\sim 2 \mathrm{~km}$ above the tropopause.
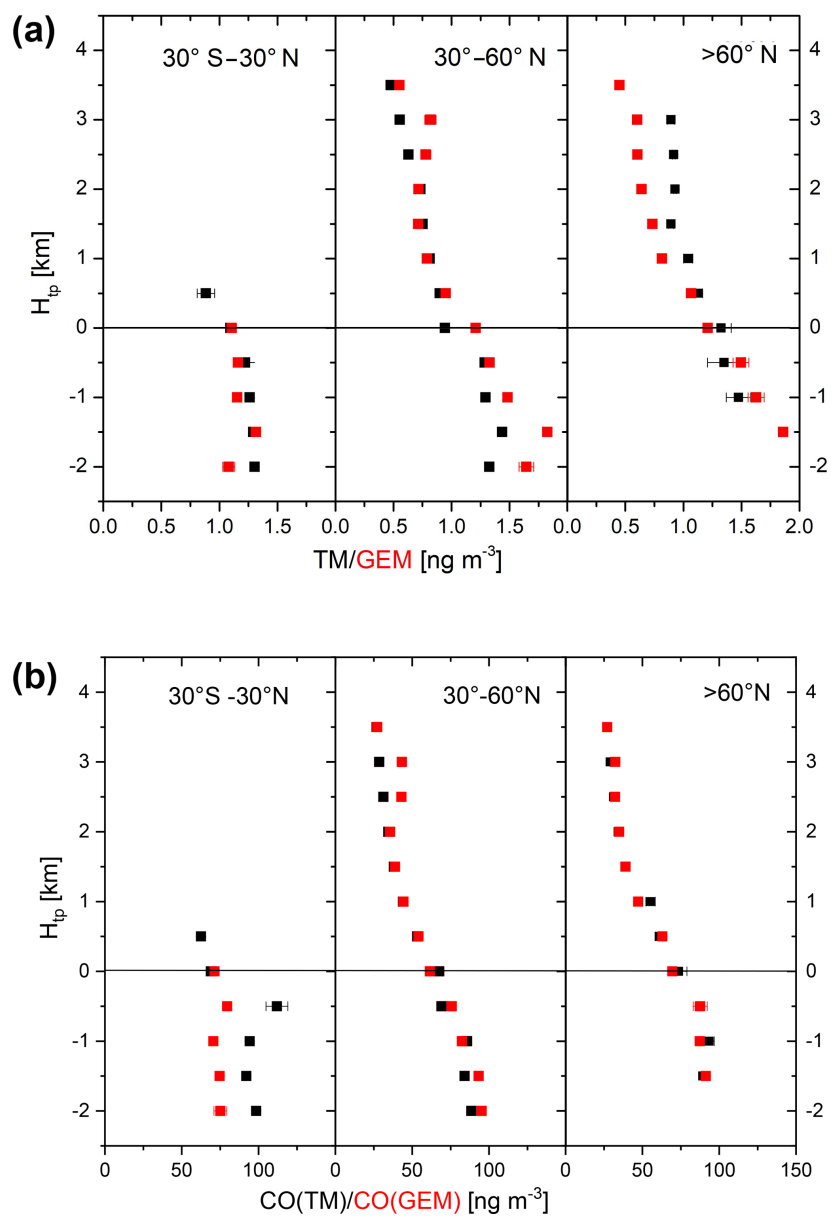

Figure 6. Vertical TM and GEM distribution relative to the thermal tropopause in summer (June-November, a). Panel (b) shows the vertical distribution of CO measured during the TM and GEM measurements. The data points represent averages and their standard errors, extreme TM and GEM values were eliminated using the Nalimov outlier test (Kaiser and Gottschalk, 1972).

Brooks et al. (2014), using a Tekran speciation system, reported decreasing GOM concentrations above GOM maxima at $\sim 4 \mathrm{~km}$ altitude above ground. They also found that GEM concentrations are independent of altitude between ground and $6 \mathrm{~km}$ altitude for most of the year. Only in April, May and June GEM concentrations decreased with increasing altitude, possibly because of the intensive influx of stratospheric air in this season. Gratz et al. (2015), using DOHGS measurements during the NOMADSS (Nitrogen, Oxidants, Mercury and Aerosol Distributions, Sources and Sinks), observed in June 2013 high GOM concentrations in a tropospheric air mass rich in $\mathrm{BrO}$ advected from the subtropical Pacific. Shah et al. (2016), finally, summarized the NOMADSS measurements made by DOHGS in vertical distributions of GOM and TM showing an increase of GOM concentrations from $\sim 0.03 \mathrm{ng} \mathrm{m}^{-3}$ near ground to $\sim 0.2 \mathrm{ng} \mathrm{m}^{-3}$ at an altitude of $7 \mathrm{~km}$. As TM decreased from $\sim 1.6 \mathrm{ng} \mathrm{m}^{-3}$ near ground 


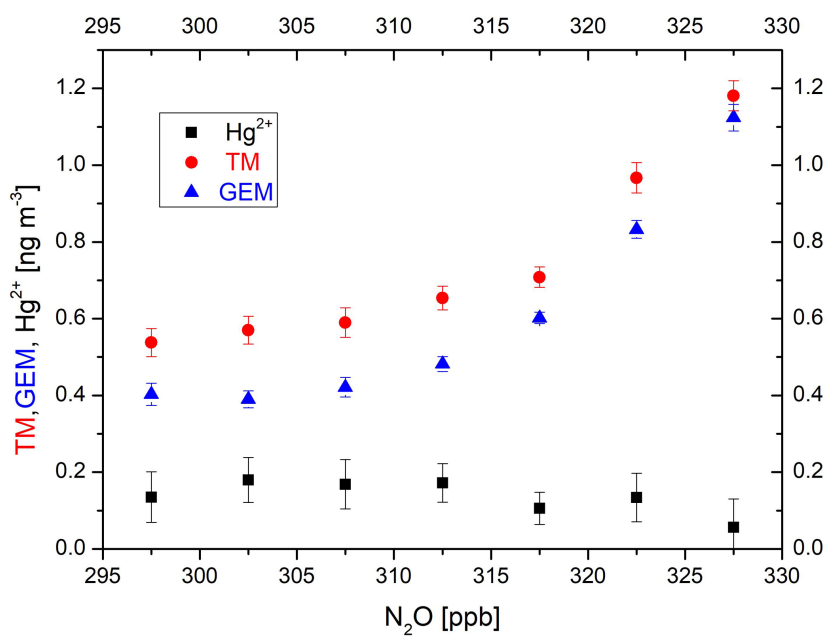

Figure 7. Stratospheric average TM and GEM concentrations in boreal winter (November-April) are binned according to the $\mathrm{N}_{2} \mathrm{O}$ mixing ratio. $\mathrm{N}_{2} \mathrm{O}$ mixing ratios were detrended using 2015 as a reference year and the $\mathrm{N}_{2} \mathrm{O}$ growth rate of $0.844 \mathrm{ppb} \mathrm{yr}^{-1}$ (Assonov et al., 2013). Vertical and horizontal bars represent the standard errors of the averages.

to $1.25 \mathrm{ng} \mathrm{m}^{-3}$ at $7 \mathrm{~km}$ altitude, $\mathrm{Hg}^{2+}$ concentrations represented less than $20 \%$ of TM at $7 \mathrm{~km}$ altitude.

Opposite to the total GEM depletion reported by Talbot et al. (2007) our post-flight processed GEM and TM concentrations were never below the detection limit of $\sim 0.05 \mathrm{ng} \mathrm{m}^{-3}$, even at $4 \mathrm{~km}$ altitude above the tropopause. However, when using the default Tekran software, small mercury peaks are occasionally not integrated resulting in erroneous zero concentrations. We thus surmise that the zero GEM concentrations reported by Talbot et al. (2007) were not real but an artifact due to incorrect default integration of the Tekran raw signal (Swartzendruber et al., 2009; Slemr et al., 2016; Ambrose, 2017). We also note that Talbot et al. (2007) reckon their measurements to represent GEM although their inlet system is very similar to that of CARIBIC (Slemr et al., 2014) with proven transmission of GOM. As for CARIBIC, the measurements by Talbot et al. (2007) are thus more likely close to those of TM.

For the UT Lyman and Jaffe (2012) report $\mathrm{Hg}^{2+}$ $(\mathrm{GOM}+\mathrm{PBM}=\mathrm{TM}-\mathrm{GEM})$ concentrations varying between zero and $\sim 0.25 \mathrm{ng} \mathrm{m}^{-3}$ at TM concentration of $\sim$ $1 \mathrm{ng} \mathrm{m}^{-3}$. Shah et al. (2016) find in June and July 2013 average $\mathrm{Hg}^{2+}$ concentration of $\sim 0.2 \mathrm{ng} \mathrm{m}^{-3}$ at an altitude of $7 \mathrm{~km}$ over USA at TM concentrations of $\sim 1.25 \mathrm{ng} \mathrm{m}^{-3}$, i.e., representing less than $20 \%$ of TM. Taking into account that we compare TM and GEM measurements from different flights (unlike DOHGS, which measures TM and GEM simultaneously) these findings are roughly consistent with ours.

As pointed out by Lyman and Jaffe (2012), zero TM concentrations at $\sim 2 \mathrm{~km}$ above the tropopause from their em- pirical model are not conform to the observations of significant PBM concentrations in the stratosphere up to $8 \mathrm{~km}$ above the tropopause by Murphy et al. $(1998,2006)$. Gaseous $\mathrm{Hg}^{2+}(\mathrm{GOM})$ is assumed to be in equilibrium with PBM. An extrapolation of the equilibria observed at ambient air temperatures near ground (Rutter and Schauer, 2007; Amos et al., 2012) to some $-50^{\circ} \mathrm{C}$ around the tropopause indicates that almost all $\mathrm{Hg}^{2+}$ will be attached to particles. Substantial PBM concentrations observed by Murphy et al. (1998, 2006) up to $8 \mathrm{~km}$ above the tropopause together with our TM data obtained during some 400 CARIBIC flights made between 2005 and 2016 (including those with default Tekran raw signal integration) thus exclude the possibility that TM disappears at $\sim 2 \mathrm{~km}$ above the tropopause. We also note that Murphy et al. $(1998,2006)$ could not detect any PBM in the troposphere at and below $5 \mathrm{~km}$ above ground. Non-detectable PBM in equilibrium with GOM at the still low air temperatures at these altitudes is another piece of evidence inconsistent with generally high $\mathrm{Hg}^{2+}$ concentrations in the UT.

In summary, it is plausible that our TM data currently provide the most representative picture of its UT/LMS distribution and seasonal variation. Our GEM measurements rely on the questionable performance of the GOM quartz wool traps and the difference between TM and GEM is statistically compromised by not being measured along exactly the same routes and altitudes above the tropopause. Despite this, our TM and GEM observations suggest that $\mathrm{Hg}^{2+}$ is not the dominating component of TM in the UT. Our observation of larger contributions of $\mathrm{Hg}^{2+}$ to $\mathrm{TM}$ in the stratosphere are consistent with the observations of substantial PBM concentrations in UT/LS by Murphy et al. $(1998,2006)$. As GEM measurements made by us were always above the detection limit, we surmise also the existence of significant GEM concentrations in the stratosphere up to $4 \mathrm{~km}$ above the tropopause.

\subsection{Stratospheric lifetime of TM and GEM}

Stratospheric lifetime of a trace gas is defined as atmospheric burden of a compound divided by its stratospheric sink (SPARC Report, Ko et al., 2013). To determine it for TM and GEM we use here the relative approach (described by Volk et al. (1997) utilizing the CARIBIC $\mathrm{N}_{2} \mathrm{O}$ measurements (Assonov et al., 2013) as reference tracer. $\mathrm{N}_{2} \mathrm{O}$, with a lifetime of $\sim 120$ years is nearly uniformly distributed in the troposphere, with little seasonal variation and is removed in the stratosphere (Nevison et al., 2011). In comparison with $\mathrm{SF}_{6}$ as chronological tracer, $\mathrm{N}_{2} \mathrm{O}$ has the advantage of a much smaller latitudinal gradient in the troposphere and of nearly constant growth rate in the last two decades. Figure 6 shows winter (November-April) average stratospheric TM and GEM concentrations as a function of $\mathrm{N}_{2} \mathrm{O}$ mixing ratios. In this plot $\mathrm{N}_{2} \mathrm{O}$ mixing ratios were detrended using 2015 as a reference year and the $\mathrm{N}_{2} \mathrm{O}$ growth rate of $0.844 \mathrm{ppb} \mathrm{yr}^{-1}$ (Assonov et al., 2013). 
TM and GEM concentrations in Fig. 6 start at $1.18 \pm 0.27$ $(n=48)$ and $1.12 \pm 0.21(n=35) \mathrm{ng} \mathrm{m}^{-3}$, respectively, in the $325-330 \mathrm{ppb}$ bin of $\mathrm{N}_{2} \mathrm{O}$ mixing ratios and they drop to $0.59 \pm 0.13(n=12)$ and $0.42 \pm 0.10(n=16) \mathrm{ng} \mathrm{m}^{-3}$, respectively, in the 305-310 ppb bin. The difference between TM and GEM concentrations is not statistically significant in the 325-330 ppb bin of $\mathrm{N}_{2} \mathrm{O}$ mixing ratios, i.e., in the UT as already discussed in Sect. 3.3. However, at lower $\mathrm{N}_{2} \mathrm{O}$ mixing ratios, GEM concentrations are systematically smaller than those of TM at the $99 \%$ significance level. The TMGEM difference (i.e., $\mathrm{Hg}^{2+}$ concentration in the gas phase , GOM, and on particles, PBM) is increasing with decreasing $\mathrm{N}_{2} \mathrm{O}$ mixing ratios and levels off at $\sim 0.17 \mathrm{ng} \mathrm{m}^{-3}$ at $\mathrm{N}_{2} \mathrm{O}$ mixing ratios below $315 \mathrm{ppb}$ representing $\sim 30 \%$ of TM concentrations. As mentioned in the experimental section, the CARIBIC trace gas inlet is not designed for collection of particles and, consequently, we presume to measure only $\mathrm{Hg}^{2+}$ on $70 \%$ of particles. If all $\mathrm{Hg}^{2+}$ (i.e., TM-GEM) were on particles as predicted by extrapolation of $\mathrm{Hg}^{2+}$ gasparticle partitioning equilibrium (Rutter and Schauer, 2007; Amos et al., 2012) from ambient temperature to temperatures at the tropopause then the unbiased $\mathrm{Hg}^{2+}$ and TM concentrations would be $\sim 0.24$ and $\sim 0.66 \mathrm{ng} \mathrm{m}^{-3}$, respectively, at $\mathrm{N}_{2} \mathrm{O}$ mixing ratios below $310 \mathrm{ppb}$.

The small decrease of TM and GEM occurring below $315 \mathrm{ppb} \mathrm{N}_{2} \mathrm{O}$ points to a long stratospheric lifetime of both TM and GEM. Correlations of all TM and GEM concentrations at $\mathrm{N}_{2} \mathrm{O}$ mixing ratios $<315 \mathrm{ppb}$ vs. $\mathrm{N}_{2} \mathrm{O}$ yield slopes of $6.30 \pm 2.96 \mathrm{pg} \mathrm{m}^{-3} \mathrm{ppb}^{-1}(n=46, R=0.2947$, significance $>95 \%)$ and $6.13 \pm 1.82 \mathrm{pg} \mathrm{m}^{-3} \mathrm{ppb}^{-1}(n=63, R=$ 0.3909 , significance $>99 \%$ ), for TM and GEM, respectively. Using a stratospheric $\mathrm{N}_{2} \mathrm{O}$ lifetime of $122 \pm 24$ years (Volk et al., 1997) we arrive at stratospheric TM and GEM lifetimes of $72 \pm 37$ and $74 \pm 27$ years, respectively. The uncertainties calculated from the slope uncertainties and the uncertainty of $\mathrm{N}_{2} \mathrm{O}$ lifetime are probably lower limits because of the narrow range of encountered $\mathrm{N}_{2} \mathrm{O}$ mixing ratios at cruise altitudes of the CARIBIC aircraft (Assonov et al., 2013). We note that our stratospheric TM and GEM lifetimes are not "relatively short" as claimed by Lyman and Jaffe (2012). We think that their TM and GEM concentrations were measured within the region of mixing of stratospheric with tropospheric air. Figure 6 shows that TM and GEM vs. $\mathrm{N}_{2} \mathrm{O}$ correlations would result in much shorter lifetimes when data at $\mathrm{N}_{2} \mathrm{O}$ mixing ratios larger than $315 \mathrm{ppb}$ were included. With the calculated uncertainties the stratospheric TM lifetime cannot be distinguished from that of GEM. A more precise estimate of TM and GEM stratospheric lifetimes will require measurements with research aircraft capable of flying at higher altitudes.

Data in Fig. 6 allow us to correlate $\mathrm{Hg}^{2+}$ (TM - GEM) with GEM as done by Lyman and Jaffe (2012). $\mathrm{Hg}^{2+}$ is negatively correlated with GEM with a slope of $-0.13 \pm 0.04(n=$ $\left.7, R^{2}=0.712\right)$ and $-0.31 \pm 0.04\left(n=7, R^{2}=0.919\right)$ when averages and medians are used, respectively. Chemical conversion of GEM into $\mathrm{Hg}^{2+}$ without any $\mathrm{Hg}^{2+}$ losses would yield a slope of -1 and slopes near this value were reported for the free troposphere by Swartzendruber et al. (2006) and for the UT by Lyman and Jaffe (2012). Our slopes in the stratosphere are substantially greater than -1 and somewhat greater than -0.53 reported by Lyman and Jaffe (2012) for stratosphere-influenced air masses. Slopes greater than -1 imply losses of $\mathrm{Hg}^{2+}\left(\mathrm{Hg}^{2+}\right.$ yield of GEM oxidation is smaller than the stoichiometry of the reaction) and result in decreasing TM concentrations with increasing $\mathrm{Hg}^{2+}$ concentrations in the stratosphere.

A reduction of TM concentration from $\sim 1.2 \mathrm{ng} \mathrm{m}^{-3}$ in tropospheric air to $\sim 0.66 \mathrm{ng} \mathrm{m}^{-3}$ in stratospheric air is too large to be explained by the aerosol bias induced by the incomplete particle sampling mentioned above and requires the presence of an $\mathrm{Hg}^{2+}$ removal process. As already proposed by Lyman and Jaffe (2012) such a removal process requires the oxidation of GEM into $\mathrm{Hg}^{2+}$, followed by attachment of $\mathrm{Hg}^{2+}$ to stratospheric (mainly sulfate) particles, and their removal by gravitational sedimentation and/or scavenging by clouds (Menzies and Tratt, 1995; Rasch et al., 2008; Wilson et al., 2008). We note that air mass exchange is also taking an important part in removing sulfate particles from the stratosphere but TM concentrations would not change without sedimentation and/or scavenging of $\mathrm{Hg}^{2+}$ on particles. The oxidation and subsequent attachment to particles could be a local process in the vicinity of extratropical tropopause layer (exTL) or a non-local process in the tropical upper troposphere (TTL) and during the transport from the TTL to the location of the IAGOS-CARIBIC measurements in the LMS.

If all stratospheric TM were $\mathrm{Hg}^{2+}$ and become attached to particles, then the stratospheric lifetime of TM would be given by the stratospheric lifetime of particles of several years (Waugh and Hall, 2002; Friberg et al., 2018). Substantially longer TM and GEM stratospheric lifetimes of $\sim 70$ years suggest that the stratospheric GEM is oxidized higher up in the stratosphere (Ko et al., 2013). Our TM and GEM stratospheric lifetimes are comparable to COS lifetime of $64 \pm 21$ years (Barkley et al., 2008) whose oxidation by photolysis and the reaction with $\mathrm{O}\left({ }^{3} \mathrm{P}\right)$ in the stratosphere is a major source of stratospheric sulfate aerosol and is located predominantly in tropics at an altitude of $\sim 30 \mathrm{~km}$ (Brühl et al., 2012). Long stratospheric lifetimes are governed by the rate of delivery of a substance to its loss region (Ko et al., 2013). Comparable stratospheric lifetimes of TM, GEM and COS thus suggest a similar location of their stratospheric loss regions. At $\sim 30 \mathrm{~km}$ altitude GEM could be oxidized by $\mathrm{Br}$ atoms released by the photolysis of halons and/or by reactions with $\mathrm{O}$ atoms (Ko et al., 2013). Collocation of stratospheric loss regions of COS and GEM supports the hypothesis of close relation of stratospheric mercury to stratospheric sulfur (COS + sulfate particles) described by Wilson et al. (2008). 


\section{Conclusions and outlook}

The obvious implication of the long stratospheric TM and GEM lifetimes is that most atmospheric mercury is oxidized in the troposphere. The second direct implication is that if the lifetime of GEM in the stratosphere with its very high $\mathrm{O}_{3}$ mixing ratios (1 ppm and more) is quite long, then the $\mathrm{GEM}+\mathrm{O}_{3}$ reaction is unlikely to be important in the troposphere with its low $\mathrm{O}_{3}$ abundance. This implies that either the reaction does not take place or that its primary reaction product is instable. Moreover, with very low stratospheric $\mathrm{H}_{2} \mathrm{O}$ mixing ratios below $10 \mathrm{ppm}, \mathrm{OH}$ is also an unlikely oxidant for GEM in the stratosphere. The most plausible remaining stratospheric oxidants are $\mathrm{Br}$ atoms originating from the decomposition of halons and some halocarbons with a possible contribution of $\mathrm{O}$ atoms.

The regular intercontinental IAGOS-CARIBIC flights provide an insight into the large-scale distribution of TM and GEM in the UT/LMS and its seasonal variation. Post-flights processed data with better accuracy and higher precision reveal a seasonal variation of vertical TM distribution in the UT/LMS, which is similar to most of the trace gases with sources in the troposphere, such as $\mathrm{CH}_{4}$ and $\mathrm{CO}$. Importantly, even at altitudes of up to $4 \mathrm{~km}$ above the thermal tropopause TM concentrations are still $\sim 0.5 \mathrm{ng} \mathrm{m}^{-3}, 1$ order of magnitude above the instrumental detection limit. We have never observed zero TM or GEM concentrations and attribute earlier reports about them to an insufficiency in the default signal integration of the Tekran instrument.

Latitudinal TM distribution in the UT during the flights to South America and South Africa were found to be strongly influenced by biomass burning. Although TM and GEM were not measured at the same place and at the same time, the data collectively show that their concentrations in the UT are similar and $\mathrm{Hg}^{2+}$ is not a dominating component of TM. Larger $\mathrm{Hg}^{2+}$ (TM - GEM) concentrations were observed only in the LMS.

Lower TM concentrations were generally observed in LMS with the pronounced gradient just around the tropopause. We attribute this gradient to mixing of tropospheric air with stratospheric air depleted of mercury. The conservative character of TM measurements implicates thus a loss process by oxidation to $\mathrm{Hg}^{2+}$, its attachment to particles and their subsequent removal by gravitational sedimentation and/or scavenging by clouds. Substantial stratospheric PBM concentrations reported by Murphy et al. $(1998,2006)$ and GOM/PBM equilibria (Rutter and Schauer, 2007; Amos et al., 2012) extrapolated to temperatures in the LMS support this hypothesis.

Correlations of TM and GEM with $\mathrm{N}_{2} \mathrm{O}$ as a reference substance show statistically the same TM and GEM concentrations in the UT. In the $\mathrm{N}_{2} \mathrm{O}$ range of 330 and $315 \mathrm{ppb}$ TM and GEM concentrations rapidly decrease with decreasing $\mathrm{N}_{2} \mathrm{O}$ mixing ratios due to mixing of tropospheric air with stratospheric air depleted of mercury. Below $315 \mathrm{ppb}$ until $295 \mathrm{ppb}$ of $\mathrm{N}_{2} \mathrm{O}$, TM and GEM concentrations hardly change. TM and GEM lifetimes of $72 \pm 37$ and $74 \pm 27$ years, respectively, were calculated from correlations of TM and GEM vs. $\mathrm{N}_{2} \mathrm{O}$ below $315 \mathrm{ppb}$, albeit with large uncertainties caused by our limited altitude range and the resulting narrow range of $\mathrm{N}_{2} \mathrm{O}$ mixing ratios between 315 and $295 \mathrm{ppb}$. Measurements of TM, GEM and $\mathrm{N}_{2} \mathrm{O}$ to higher altitudes above the tropopause (i.e., to $\mathrm{N}_{2} \mathrm{O}$ mixing ratios substantially below $290 \mathrm{ppb}$ ) are needed to better constrain the stratospheric TM and GEM lifetimes.

Stratospheric lifetimes of TM and GEM are comparable to the COS stratospheric lifetime of $64 \pm 21$ years (Barkley et al., 2008), which is, in volcanically quiet periods, the major precursor of sulfate particles in the stratosphere (Wilson et al., 2008). Comparable COS and GEM stratospheric lifetimes suggest collocation of their loss regions. This coincidence corroborates the hypothesis of $\mathrm{Hg}^{2+}$ attachment to sulfate particles and their removal by gravitational sedimentation and scavenging by clouds. This hypothesis, first proposed by Lyman and Jaffe (2012), could be directly tested in future by quantitative measurements of $\mathrm{Hg} / \mathrm{S}$ ratios on stratospheric particles. Such measurements would also better constrain the mercury fluxes across the tropopause.

Mercury measurements onboard IAGOS-CARIBIC were stopped in March 2016 and the space of the mercury instrument is now occupied by other instruments. The reason for the termination of the mercury measurements was the feeling that, with the present instrumentation, we will only reproduce the existing data. An improved instrumentation including reliable speciation technique is needed to gain new insights. Any institution capable of providing and maintaining such an instrument is welcomed to participate in future IAGOS-CARIBIC measurements. For details please consult the CARIBIC coordinator Andreas Zahn.

Data availability. The data are stored at the GMOS data bank and can be obtained under http://sdi.iia.cnr.it/geoint/publicpage/GMOS/ gmos_aircraft.zul (GMOS, 2018).

\section{The Supplement related to this article is available online at https://doi.org/10.5194/acp-18-12329-2018- supplement.}

Author contributions. All authors except JB are members of the CARIBIC team and as such carried out the measurements and provided the chemical (mercury by $\mathrm{AW}$ and $\mathrm{RE}, \mathrm{CH}_{4}, \mathrm{~N}_{2} \mathrm{O}, \mathrm{CO}$, NMHC by CAMB and AR-S, particles by MH and BGM, acetonitrile, $\mathrm{O}_{3}, \mathrm{H}_{2} \mathrm{O}$ by $\mathrm{MN}, \mathrm{AZ}$ and $\mathrm{HB}, \mathrm{NO}$ and $\mathrm{NO}_{y}$ by $\mathrm{HZ}$ ) and the meteorological (model and trajectories by $\mathrm{PvV}$ ) data on which the analysis is based. FS processed the data and prepared the manuscript. All authors contributed to discussions of the analysis and the manuscript. 
Competing interests. The authors declare that they have no conflict of interest.

Acknowledgements. We thank Lufthansa Airlines and Lufthansa Technik for their commitment and support. We also thank Jan Boedewadt from HZG for modifying the Tekran instrument for deployment in the CARIBIC container. The development and operation of the CARIBIC system has been financially supported by the German Ministry of Education and Science (AFO 2000, IAGOS-D), by the European Commission's DGXII Environment RTD 4th and 5th Framework programs, by grants from the Max Planck Society and from Frankfurt Airport.

The article processing charges for this open-access publication were covered by the Max Planck Society.

Edited by: Aurélien Dommergue

Reviewed by: two anonymous referees

\section{References}

AMAP/UNEP: Technical Background Report for the Global Mercury Assessment, UNEP Chemicals 15 Branch,s, available at: https://www.unenvironment.org/resources/report/technicalbackground-report-global-atmospheric-mercury-assessment2013, last access: 16 August 2018.

Ambrose, J. L.: Improved methods for signal processing in measurements of mercury by $\operatorname{Tekran}^{\circledR}$ 2537A and 2537B instruments, Atmos. Meas. Tech., 10, 5063-5073, https://doi.org/10.5194/amt-10-5063-2017, 2017.

Ambrose, J. L., Lyman, S. N., Huang, J., Gustin, M. S., and Jaffe, D. A.: Fast time resolution oxidized mercury measurements during the Reno Atmospheric Mercury Intercomparison Experiment (RAMIX), Environ. Sci. Technol., 47, 7285-7294, 2013.

Ambrose, J. L., Gratz, L. E., Jaffe, D. A., Campos, T., Flocke, F. M., Knapp, D. J., Stechman, D. M., Stell, M., Weinheimer, A. J., Cantrell, C. A., and Mauldin III, R. L.: Mercury emission ratios from coal-fired power plants in the southeastern United States during NOMADDS, Environ. Sci. Technol., 49, 10389-10397, 2015.

Amos, H. M., Jacob, D. J., Holmes, C. D., Fisher, J. A., Wang, Q., Yantosca, R. M., Corbitt, E. S., Galarneau, E., Rutter, A. P., Gustin, M. S., Steffen, A., Schauer, J. J., Graydon, J. A., Louis, V. L. St., Talbot, R. W., Edgerton, E. S., Zhang, Y., and Sunderland, E. M.: Gas-particle partitioning of atmospheric $\mathrm{Hg}(\mathrm{II})$ and its effect on global mercury deposition, Atmos. Chem. Phys., 12, 591-603, https://doi.org/10.5194/acp-12-591-2012, 2012.

Andreae, M. O. and Merlet, P.: Emission of trace gases and aerosols from biomass burning, Global Biogeochem. Cy., 15, 955-966, 2001.

Ariya, P. A., Amyot, M., Dastoor, A., Deeds, D., Feinberg, A., Kos, G., Poulain, A., Ryjkov, A., Semeniuk, K., Subir, M., and Toyota, K.: Mercury physicochemical and biogeochemical transformation in the atmosphere and at atmospheric interfaces: A review and future direction, Chem. Rev., 115, 3760-3802, 2015.

Assonov, S. S., Brenninkmeijer, C. A. M., Schuck, T., and Umezawa, T.: $\mathrm{N}_{2} \mathrm{O}$ as a tracer of mixing stratospheric and tropo- spheric air based on CARIBIC data with applications for $\mathrm{CO}_{2}$, Atmos. Environ., 79, 769-779, 2013.

Banic, C. M., Beauchamp, S. T., Tordon, R. J., Schroeder, W. H., Steffen, A., Anlauf, K. A., and Wong, K. H. T.: Vertical distribution of gaseous elemental mercury in Canada, J. Geophys. Res., 108, 4264, https://doi.org/10.1029/2002JD002116, 2003.

Barkley, M. P., Palmer, P. I., Boone, C. D., Bernath, P. F., and Sunthralanigam, P.: Global distributions of carbonyl sulfide in the upper troposphere and stratosphere, Geophys. Res. Lett., 35, L14810, https://doi.org/10.1029/2008GL034270, 2008.

Baron, P. A. and Willeke, K.: Aerosol Measurements: Principles, Techniques and Applications, John Wiley and Sons, New York, 1131 pp., 2001.

Bieser, J., Slemr, F., Ambrose, J., Brenninkmeijer, C., Brooks, S., Dastoor, A., DeSimone, F., Ebinghaus, R., Gencarelli, C. N., Geyer, B., Gratz, L. E., Hedgecock, I. M., Jaffe, D., Kelley, P., Lin, C.-J., Jaegle, L., Matthias, V., Ryjkov, A., Selin, N. E., Song, S., Travnikov, O., Weigelt, A., Luke, W., Ren, X., Zahn, A., Yang, X., Zhu, Y., and Pirrone, N.: Multi-model study of mercury dispersion in the atmosphere: vertical and interhemispheric distribution of mercury species, Atmos. Chem. Phys., 17, 69256955, https://doi.org/10.5194/acp-17-6925-2017, 2017.

Brenninkmeijer, C. A. M., Crutzen, P., Boumard, F., Dauer, T., Dix, B., Ebinghaus, R., Filippi, D., Fischer, H., Franke, H., Frieß, U., Heintzenberg, J., Helleis, F., Hermann, M., Kock, H. H., Koeppel, C., Lelieveld, J., Leuenberger, M., Martinsson, B. G., Miemczyk, S., Moret, H. P., Nguyen, H. N., Nyfeler, P., Oram, D., O’Sullivan, D., Penkett, S., Platt, U., Pupek, M., Ramonet, M., Randa, B., Reichelt, M., Rhee, T. S., Rohwer, J., Rosenfeld, K., Scharffe, D., Schlager, H., Schumann, U., Slemr, F., Sprung, D., Stock, P., Thaler, R., Valentino, F., van Velthoven, P., Waibel, A., Wandel, A., Waschitschek, K., Wiedensohler, A., Xueref-Remy, I., Zahn, A., Zech, U., and Ziereis, H.: Civil Aircraft for the regular investigation of the atmosphere based on an instrumented container: The new CARIBIC system, Atmos. Chem. Phys., 7, 4953-4976, https://doi.org/10.5194/acp-7-4953-2007, 2007.

Brooks, S., Ren, X., Cohen, M., Luke, W.T., Kelley, P., Artz, R., Hynes, A., Landing, W., and Martos, B.: Airborne vertical profiling of mercury speciation near Tullahoma, TN, USA, Atmosphere, 5, 557-574, 2014.

Brühl, C., Lelieveld, J., Crutzen, P. J., and Tost, H.: The role of carbonyl sulphide as a source of stratospheric sulphate aerosol and its impact on climate, Atmos. Chem. Phys., 12, 1239-1253, https://doi.org/10.5194/acp-12-1239-2012, 2012.

Brunke, E.-G., Labuschagne, C., and Slemr, F.: Gaseous mercury emissions from a fire in the Cape Peninsula, South Africa, during January 2000, Geophys. Res. Lett., 28, 1483-1486, 2001.

Dibble, T. S., Zelie, M. J., and Mao, H.: Thermodynamics of reactions of $\mathrm{ClHg}$ and $\mathrm{BrHg}$ radicals with atmospherically abundant free radicals, Atmos. Chem. Phys., 12, 10271-10279, https://doi.org/10.5194/acp-12-10271-2012, 2012.

Duncan, B. R., Martin, R. V., Staudt, A. C., Yevich, R., and Logan, J. A.: Interannual and seasonal variability of biomass burning emissions constrained by satellite observations, J. Geophys. Res., 108, 4100, https://doi.org/10.1029/2002JD002378, 2003.

Ebinghaus, R. and Slemr, F.: Aircraft measurements of atmospheric mercury over southern and eastern Germany, Atmos. Environ., 34, 895-903, 2000. 
Ebinghaus, R., Slemr, F., Brenninkmeijer, C. A. M., van Velthoven, P., Zahn, A., Hermann, M., O'Sullivan, D. A., and Oram, D. E.: Emissions of gaseous mercury from biomass burning in South America in 2005 observed during CARIBIC flights, Geophys. Res. Lett., 34, L08813, https://doi.org/10.1029/2006GL028866, 2007.

Friberg, J., Martinsson, B. G., Andersson, S. M., and Sandvik, O. S.: Volcanic impact on the climate - the stratospheric aerosol load in the period 2006-2015, Atmos. Chem. Phys., 18, 11149-11169, https://doi.org/10.5194/acp-18-11149-2018, 2018.

Friedli, H. R., Radke, L. F., and Yu, J. Y.: Mercury in smoke from biomass fires, Geophys. Res. Lett., 28, 3223-3226, 2001.

Friedli, H. R., Radke, L. F., Lu, J. Y., Banic, C. M., Leaitch, W. R., and MacPherson, J. I.: Mercury emissions from burning of biomass from temperate North American forests: laboratory and airborne measurements, Atmos. Environ., 37, 253-267, $2003 \mathrm{a}$.

Friedli, H. R., Radke, L. F., Prescott, R., Hobbs, P. V., and Sinha, P.: Mercury emissions from the August 2001 wildfires in Washington State and an agricultural waste fire in Oregon and atmospheric mercury budget estimates, Global Biogeochem. Cy., 17, 1039, https://doi.org/10.1029/2002GB001972, 2003b.

Friedli, H. R., Radke, L. F., Prescott, R., Li, P., Wo, J.H., and Carmichael, G. R.: Mercury in the atmosphere around Japan, Korea, and China as observed during the 2001 ACE-Asia field campaign: Measurements, distributions, sources, and implications, J. Geophys. Res., 109, D19S25, https://doi.org/10.1029/2003JD004244, 2004.

Friedli, H. R., Arellano, A. F., Cinnirella, S., and Pirrone, N.: Initial estimates of mercury emissions to the atmosphere from global biomass burning, Environ. Sci. Technol., 43, 3507-3513, 2009.

Gettelman, A., Hoor, P., Pan, L. L., Randel, W. J., Hegglin, M. I., and Birner, T.: The extratropical upper troposphere and lower stratosphere, Rev. Geophys., 49, RG3003, https://doi.org/10.1029/2011RG000355, 2011.

GMOS: Aircraft campaigns, available at: http://sdi.iia.cnr.it/ geoint/publicpage/GMOS/gmos_aircraft.zul, last access: $21 \mathrm{Au}-$ gust 2018.

Gratz, L. E., Ambrose, J. L., Jaffe, D. A., Shah, V., Jaeglé, L., Stutz, J., Festa, J., Spolaor, M., Tsai, C., Selin, N. E., Song, S., Zhou, X., Weinheimer, A. J., Knapp, D. J., Montzka, D. D., Flocke, F. M., Campos, T. L., Apel, E., Hornbrook, R., Blake, N. J., Hall, S., Tyndall, G. S., Reeves, M., Stechman, D., and Stell, M.: Oxidation of mercury by bromine in the subtropical Pacific free troposphere, Geophys. Res. Lett., 42, 10494-10502, https://doi.org/10.1002/2015GL066645, 2015.

Gustin, M. S., Huang, J., Miller, M. B., Peterson, C., Jaffe, D. A., Ambrose, J., Finley, B. D., Lyman, S. N., Call, K., Talbot, R., Feddersen, D., Mao, H., and Lindberg, S. E.: Do we understand what the mercury speciation instruments are actually measuring? Results of RAMIX, Environ. Sci. Technol., 47, 7295-7906, 2013.

Gustin, M. S., Amos, H. M., Huang, J., Miller, M. B., and Heidecorn, K.: Measuring and modeling mercury in the atmosphere: a critical review, Atmos. Chem. Phys., 15, 5697-5713, https://doi.org/10.5194/acp-15-5697-2015, 2015.

Holmes, C. D., Jacob, D. J., Corbitt, E. S., Mao, J., Yang, X., Talbot, R., and Slemr, F.: Global atmospheric model for mercury including oxidation by bromine atoms, Atmos. Chem.
Phys., 10, 12037-12057, https://doi.org/10.5194/acp-10-120372010, 2010.

Holton, J. R., Haynes, P. H., McIntyre, M. E., Douglass, A. R., Rood, R. B., and Pfister, L.: Stratosphere-troposphere exchange, Rev. Geophys., 33, 403-439, 1995.

Horowitz, H. M., Jacob, D. J., Zhang, Y., Dibble, T. S., Slemr, F., Amos, H. M., Schmidt, J. A., Corbitt, E. S., Marais, E. A., and Sunderland, E. M.: A new mechanism for atmospheric mercury redox chemistry: implications for the global mercury budget, Atmos. Chem. Phys., 17, 6353-6371, https://doi.org/10.5194/acp17-6353-2017, 2017.

Hynes, A. J., Everhart, S., Bauer, D., Remeika, J., and Tatum Ernest, C.: In situ and denuder-based measurements of elemental and reactive gaseous mercury with analysis by laser-induced fluorescence - results from the Reno Atmospheric Mercury Intercomparison Experiment, Atmos. Chem. Phys., 17, 465-483, https://doi.org/10.5194/acp-17-465-2017, 2017.

Kaiser, R. and Gottschalk, G.: Elementare Tests zur Beurteilung von Meßdaten, Bibliographisches Institut, Mannheim, 1972.

Ko, M. K. W., Newman, P. A., Reimann, S., and Strahan, S. E. (Eds.): Lifetimes of stratospheric ozone-depleting substances, their replacements, and related species, SPARC Report No. 6, WCRP-15/2013, December 2013.

Kunz, A., Konopka, P., Müller, R., and Pan, L. L.: Dynamical tropopause based on isentropic potential vorticity gradients, J. Geophys. Res., 116, D01110, https://doi.org/10.1029/2010JD014343, 2011.

Lin, C.-J., Pongprueksa, P., Lindberg, S. E., Pehkonen, S. O., Byun, D., and Jang, C.: Scientific uncertainties in atmospheric mercury models. I. Model science evaluation, Atmos. Environ, 40, 29112928, 2006.

Lindberg, S., Bullock, R., Ebinghaus, R., Engstrom, D., Feng, X., Fitzgerald, W., Pirrone, N., Prestbo, E., and Seigneur, C.: A synthesis of progress and uncertainties in attribution the sources of mercury in deposition, Ambio, 36, 19-32, 2007.

Lyman, S. N. and Jaffe, D. A.: Formation and fate of oxidized mercury in the upper troposphere and lower stratosphere, Nat. Geosci., 5, 114-117, 2012

Martinsson, B. G., Friberg, J., Andersson, S. M., Weigelt, A., Hermann, M., Assmann, D., Voigtländer, J., Brenninkmeijer, C. A. M., van Velthoven, P. J. F., and Zahn, A.: Corrigendum to "Comparison between CARIBIC Aerosol Samples Analysed by Accelerator-Based Methods and Optical Particle Counter Measurements" published in Atmos. Meas. Tech., 7, 2581-2596, 2014, Atmos. Meas. Tech., 8, 367-367, https://doi.org/10.5194/amt-8-367-2015, 2015.

Menzies, R. T. and Tratt, D. M.: Evidence of seasonally dependent stratosphere-troposphere exchange and purging of lower stratospheric aerosol from a multiyear lidar data set, J. Geophys. Res. 100, 3139-3148, 1995.

Mergler, D., Anderson, H. A., Chan, L. H. M., Mahaffey, K. R., Murray, M., Sakamoto, M., and Stern, A. H.: Methyl mercury exposure and health effects in humans: A worldwide concern, Ambio, 36, 3-11, 2007.

Murphy, D. M., Thomson, D. S., and Mahoney, M. J.: In situ measurements of organics, meteoritic material, mercury, and other elements in aerosols at 5 to 19 kilometers, Science, 282, 1664 1669, 1998. 
Murphy, D. M., Hudson, P. K., Thomson, D. S., Sheridan, P. J., and Wilson, J. C.: Observations of mercury-containing aerosols, Environ. Sci. Technol., 40, 3163-3167, 2006.

Nevison, C. D., Dlugokencky, E., Dutton, G., Elkins, J. W., Fraser, P., Hall, B., Krummel, P. B., Langenfelds, R. L., O'Doherty, S., Prinn, R. G., Steele, L. P., and Weiss, R. F.: Exploring causes of interannual variability in the seasonal cycles of tropospheric nitrous oxide, Atmos. Chem. Phys., 11, 3713-3730, https://doi.org/10.5194/acp-11-3713-2011, 2011.

Pirrone, N., Cinnirella, S., Feng, X., Finkelman, R. B., Friedli, H. R., Leaner, J., Mason, R., Mukherjee, A. B., Stracher, G. B., Streets, D. G., and Telmer, K.: Global mercury emissions to the atmosphere from anthropogenic and natural sources, Atmos. Chem. Phys., 10, 5951-5964, https://doi.org/10.5194/acp10-5951-2010, 2010.

Radke, L. F., Friedli, H. R., and Heikes, B. G.: Atmospheric mercury over the NE Pacific during spring 2002: Gradients, residence time, upper troposphere lower stratosphere loss, and long-range transport, J. Geophys. Res., 112, D19305, https://doi.org/10.1029/2005JD005828, 2007.

Rasch, P. J., Tilmes, S., Turco, R. P., Robock, A., Oman, L., Chen, C.-C., Stenchikov, G. L., and Garcia, R. R.: An overview of geoengineering of climate using stratospheric sulphate aerosols, Philos. T. R. Soc. A, 366, 4007-4037, 2008.

Rutter, A. P. and Schauer, J. J.: The effect of temperature on the gasparticle partitioning of reactive mercury in atmospheric aerosols, Atmos. Environ., 41, 8647-8657, 2007.

Scheele, M., Siegmund, P., and Van Velthoven, P.: Sensitivity of trajectories to data resolution and its dependence on the starting point: In or outside a tropopause fold, Meteorol. Appl., 3, 267273, 1996.

Scheuhammer, A. M., Meyer, M. W., Sandheinrich, M. B., and Murray, M. W.: Effects of environmental methylmercury on the health of wild bird, mammals, and fish, Ambio, 36, 12-18, 2007.

Selin, N. E., Jacob, D. J., Park, R. J., Yantosca, R. M., Strode, S., Jaeglé, L., and Jaffe, D.: Chemical cycling and deposition of atmospheric mercury: Global constraints from observations, J. Geophys. Res., 112, D02308, https://doi.org/10.1029/2006JD007450, 2007.

Shah, V., Jaeglé, L., Gratz, L. E., Ambrose, J. L., Jaffe, D. A., Selin, N. E., Song, S., Campos, T. L., Flocke, F. M., Reeves, M., Stechman, D., Stell, M., Festa, J., Stutz, J., Weinheimer, A. J., Knapp, D. J., Montzka, D. D., Tyndall, G. S., Apel, E. C., Hornbrook, R. S., Hills, A. J., Riemer, D. D., Blake, N. J., Cantrell, C. A., and Mauldin III, R. L.: Origin of oxidized mercury in the summertime free troposphere over the southeastern US, Atmos. Chem. Phys., 16, 1511-1530, https://doi.org/10.5194/acp16-1511-2016, 2016.

Slemr, F., Ebinghaus, R., Brenninkmeijer, C. A. M., Hermann, M., Kock, H. H., Martinsson, B. G., Schuck, T., Sprung, D., van Velthoven, P., Zahn, A., and Ziereis, H.: Gaseous mercury distribution in the upper troposphere and lower stratosphere observed onboard the CARIBIC passenger aircraft, Atmos. Chem. Phys., 9, 1957-1969, https://doi.org/10.5194/acp-9-1957-2009, 2009.

Slemr, F., Weigelt, A., Ebinghaus, R., Brenninkmeijer, C., Baker, A., Schuck, T., Rauthe-Schöch, A., Riede, H., Leedham, E., Hermann, M., van Velthoven, P., Oram, D., O'Sullivan, D., Dyroff, C., Zahn, A., and Ziereis, H.: Mercury plumes in the global upper troposphere observed during flights with the CARIBIC observa- tory from May 2005 until June 2013, Atmosphere, 5, 342-369, 2014.

Slemr, F., Weigelt, A., Ebinghaus, R., Kock, H. H., Bödewadt, J., Brenninkmeijer, C. A. M., Rauthe-Schöch, A., Weber, S., Hermann, M., Becker, J., Zahn, A., and Martinsson, B.: Atmospheric mercury measurements onboard the CARIBIC passenger aircraft, Atmos. Meas. Tech., 9, 2291-2302, https://doi.org/10.5194/amt-9-2291-2016, 2016.

Sprovieri, F., Pirrone, N., Ebinghaus, R., Kock, H., and Dommergue, A.: A review of worldwide atmospheric mercury measurements, Atmos. Chem. Phys., 10, 8245-8265, https://doi.org/10.5194/acp-10-8245-2010, 2010.

Sprung, D. and Zahn, A.: Acetone in the upper troposphere/lowermost stratosphere measured by the CARIBIC passenger aircraft: Distribution, seasonal cycle, and variability, J. Geophys. Res., 115, D16301, https://doi.org/10.1029/2009JD012099, 2010.

Swartzendruber, P. C., Jaffe, D. A., Prestbo, E. M., Weiss-Penzias, P., Selin, N. E., Park, R., Jacob, D. J., Strode, S., and Jaeglé, L.: Observations of reactive gaseous mercury in the free troposphere at the Mount Bachelor Observatory, J. Geophys. Res., 111, D24301, https://doi.org/10.1029/2006JD007415, 2006.

Swartzendruber, P. C., Chand, D., Jaffe, D. A., Smith, J., Reidmiller, D., Gratz, L., Keeler, J., Strode, S., Jaeglé, L., and Talbot, R.: Vertical distribution of mercury, CO, ozone, and aerosol scattering coefficient in the Pacific Northwest during the spring 2006 INTEX-B campaign, J. Geophys. Res., 113, D10305, https://doi.org/10.1029/2007JD009579, 2008.

Swartzendruber, P. C., Jaffe, D. A., and Finley, B.: Improved fluorescence peak integration in the Tekran 2537 for applications with sub-optimal sample loadings, Atmos. Environ., 43, 36483651, 2009.

Talbot, R., Mao, H., Scheuer, E., Dibb, J., and Avery, M.: Total depletion of $\mathrm{Hg}^{0}$ in the upper troposphere - lower stratosphere, Geophys. Res. Lett., 34, L23804, https://doi.org/10.1029/2007GL031366, 2007.

Talbot, R., Mao, H., Scheuer, E., Dibb, J., Avery, M., Browell, E., Sachse, G., Vay, S., Blake, D., Huey, G., and Fuelberg, H.: Factors influencing the large-scale distribution of $\mathrm{Hg}^{\circ}$ in the Mexico City area and over the North Pacific, Atmos. Chem. Phys., 8, 2103-2114, https://doi.org/10.5194/acp-8-2103-2008, 2008.

Travnikov, O., Angot, H., Artaxo, P., Bencardino, M., Bieser, J., D'Amore, F., Dastoor, A., De Simone, F., Diéguez, M. D. C., Dommergue, A., Ebinghaus, R., Feng, X. B., Gencarelli, C. N., Hedgecock, I. M., Magand, O., Martin, L., Matthias, V., Mashyanov, N., Pirrone, N., Ramachandran, R., Read, K. A., Ryjkov, A., Selin, N. E., Sena, F., Song, S., Sprovieri, F., Wip, D., Wängberg, I., and Yang, X.: Multi-model study of mercury dispersion in the atmosphere: atmospheric processes and model evaluation, Atmos. Chem. Phys., 17, 5271-5295, https://doi.org/10.5194/acp-17-5271-2017, 2017.

Volk, C. M., Elkins, J. W., Fahey, D. W., Dutton, G. S., Gilligan, J. M., Loewenstein, M., Podolske, J. R., Chan, K. R., and Gunson, M. R.: Evaluation of source gas lifetimes from stratospheric observations, J. Geophys. Res., 102, 25543-25564, 1997.

Waugh, D. W. and Hall, T. M.: Age of stratospheric air: Theory, observations, and models, Rev. Geophys. 40, 1010, https://doi.org/10.1029/2000RG000101, 2002. 
Weigelt, A., Ebinghaus, R., Pirrone, N., Bieser, J., Bödewadt, J., Esposito, G., Slemr, F., van Velthoven, P. F. J., Zahn, A., and Ziereis, H.: Tropospheric mercury vertical profiles between 500 and $10000 \mathrm{~m}$ in central Europe, Atmos. Chem. Phys., 16, 41354146, https://doi.org/10.5194/acp-16-4135-2016, 2016 .

Weigelt, A., Slemr, F., Ebinghaus, R., Pirrone, N., Bieser, J., Bödewadt, J., Esposito, G., and van Velthoven, P. F. J.: Mercury emissions of a coal-fired power plant in Germany, Atmos. Chem. Phys., 16, 13653-13668, https://doi.org/10.5194/acp-16-136532016, 2016b.

Wilson, J. C., Lee, S.-H., Reeves, J. M., Brock, C. A., Jonsson, H. H., Lafleur, B. G., Loewenstein, M., Podolske, J., Atlas, E., Boering, K., Toon, G., Fahey, D., Bui, T. P., Diskin, G., and Moore, F.: Steady-state aerosol distributions in the extra-tropical, lower stratosphere and the processes that maintain them, Atmos. Chem. Phys., 8, 6617-6626, https://doi.org/10.5194/acp-8-6617-2008, 2008.
Zahn, A., Christner, E., van Velthoven, P. F. J., Rauthe-Schöch, A., and Brenninkmeijer, C. A. M.: Processes controlling water vapor in the upper troposphere/lowermost stratosphere: An analysis of 8 years of monthly measurements by the IAGOS-CARIBIC observatory, J. Geophys. Res.-Atmos., 119, 11505-11525, 2014. 